\title{
Water quality and communities associated with macrophytes in a shallow water-supply reservoir on an aquaculture farm
}

\author{
Sipaúba-Tavares, $L H$.* and Dias, $S G$. \\ Centro de Aquicultura, Universidade Estadual Paulista - UNESP, Via de Acesso Prof. Paulo Donato Castellane, \\ s/n, CEP 14884-900, Jaboticabal, SP, Brazil \\ *e-mail: sipauba@caunesp.unesp.br
}

Received: December 20, 2012 - Accepted: February 28, 2013 - Distributed: May 31, 2014

(With 3 figures)

\begin{abstract}
Plankton communities and macrofauna associated to aquatic macrophyte stands in a shallow water-supply reservoir ( $\left.21^{\circ} 14^{\prime} 09^{\prime \prime} \mathrm{S} ; 48^{\circ} 18^{\prime} 38^{\prime \prime} \mathrm{W}\right)$ on an aquaculture farm were compared to evaluate the relationship between organism densities and some abiotic features of the reservoir. Water and communities associated were sampled at two sites, one in an area with the predominance of Eichhornia azurea (Sw.) Kunth and the other with the predominance of Salvinia auriculata Aublet. Communities associated with macrophytes were sampled with floating quadrants $\left(0.5 \mathrm{~m}^{2}\right)$; the macrophytes were washed and plankton and macrofauna were fixated with $4 \%$ formalin and $1 \%$ lugol iodine; the specimens were then identified and counted. Plankton and macrofauna communities associated with S. auriculata and E. azurea had a similar diversity of species but different $(\mathrm{p}<0.05)$ in the abundance of associated organisms. Eichhornia azurea had the highest contents in dry and wet weight, total phosphorus, total nitrogen and organic matter. Planktonic algae were directly correlated with biomass of E. azurea. The taxa with highest densities were Rotifera and Zygnematophyceae. Results showed that the environmental variables associated with macrophytes presence in the shallow reservoir is a strong predictor of favourable conditions to maintain great diversity plankton community and macrofauna associated with plants. The role of macrophytes is important for not only stabilising the clear-water state and maintaining high diversity of organisms associated, but also it seems to be a good alternative to maintaining desirable water-supply quality for aquaculture farms.
\end{abstract}

Keywords: floating macrophytes, plankton, aquaculture, water-supply, macrofauna.

\section{Qualidade da água e comunidades associadas com macrófitas em um reservatório de abastecimento de água para uma fazenda de aquicultura}

\section{Resumo}

Este estudo objetivou comparar a composição da comunidade planctônica e a macrofauna associada aos bancos de

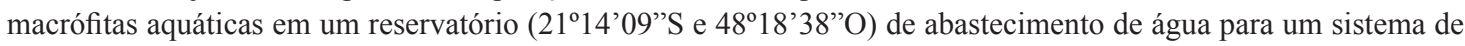
aquicultura, avaliando a relação entre a densidade dos organismos e alguns fatores abióticos da coluna d'água. As amostras de água e comunidades associadas foram coletadas em dois locais, um em área dominada por Eichhornia azurea (Sw.) Kunth e outro em área dominada por Salvinia auriculata Aublet. As comunidades associadas com as macrófitas foram amostradas utilizando o método do quadrante $\left(0,5 \mathrm{~m}^{2}\right)$, posteriormente lavadas e fixadas com formalina a $4 \%$ e lugol a 1\%; depois os indivíduos foram identificados e contados. A comunidade planctônica e macrofauna associadas à $S$. auriculata e E. azurea apresentaram similar diversidade de espécies e, diferiram $(\mathrm{p}<0,05)$ em abundância em relação aos organismos associados. Massa seca e fresca, matéria orgânica, fósforo total e nitrogênio total foram mais elevados no tecido vegetal de E. azurea do que em $S$. auriculata. As algas planctônicas foram correlacionadas diretamente com a biomassa de E. azurea. Os grupos que apresentaram as maiores densidades de espécies foram Rotifera e Zygnematophyceae. Os resultados mostraram que as variáveis ambientais associados à presença de macrófitas em reservatório raso apresentam condições favoráveis na manutenção de grande diversidade da comunidade planctônica e macrofauna associada às plantas. O papel das macrófitas não está ligado somente em manter uma água clara com elevada diversidade de organismos associados, mas também parece ser uma boa alternativa a ser adotada na manutenção da qualidade de água para abastecimento em fazenda de aquicultura.

Palavras-chave: macrófitas flutuantes, plâncton, aquicultura, abastecimento de água, macrofauna. 


\section{Introduction}

Macrophytes, which are major primary producers in shallow freshwater systems, have been reported to contribute substantially to biodiversity at the ecosystem level (Zeng et al., 2012). Macrophytes seem to have the key position in the development of the ecological state in shallow lakes.

Aquatic environments with low nutrient content usually have vegetation dominated by relatively small plants. With moderate nutrient loading, the biomass and proportion of aquatic macrophytes increases and plants can fill the entire water column (Zingel et al., 2006). The functional role of macrophytes tends to be greatest when plants fill the entire water column and when the growing season is long. Under eutrophic conditions, however, gaps may occur in plant cover either spatially (macrophytefree areas) or temporally (seasonally or between-years) (Sayder et al., 2010).

The macrophytes stands support epiphytic algae and animals as well as a variety of associated mobile animals, including zooplankton, macrofauna and fish (Albertoni et al., 2007; Christie et al., 2009). Macrophytes provide habitat and refuge for zooplanktonic filter feeders to maintain topdown control on the phytoplankton (Sandilands and Hann, 1997). Macrophytes play a central role in the control of phytoplankton and sustain a high faunal diversity.

Different species of macrophytes have been characterised by dissimilar physiology and chemical composition, which would result in the release of different types of substrates. The presence of these different substrates may affect the availability of ecological niches for different associated communities (Zeng et al., 2012).

The chemical composition of macrophytes depends on availability of main resources, light, carbon dioxide and mineral nutrients and, is closely related to the structure of the aquatic environment (Ronzhina et al., 2010). Macrophytes may affect nutrient availability in the water column and influence algal growth through allelopathic exudates and substrate high densities of phytoplankton by eating Cladocera (Zingel et al., 2006).

Macrophytes reduce phytoplankton abundance not only through direct competition for nutrients but also through the provision of habitat and invertebrate grazers (Sayder et al., 2010).

Submerged macrophytes are considered most suited as a daytime refuge, although some studies indicate the occurrence of a protective potential offered by stands of floating leaves and emergent vegetation with shelter to the zooplankton community (Onsem et al., 2010).

The number of inflowing nutrients, particularly phosphorus and nitrogen, which may cause a considerable increase of plant and other organic productivity in shallow freshwater systems, is often connected with the kind of land use of areas neighbouring shallow water systems (Kuczyńska-Kippen and Świdnicki, 2008).

Aquatic plants are highly capable of removing nutrients of the water column or sediment in their growth process, partially reducing the resulting load, thus improving water quality. Consequently, the factors that affect plankton density and community structure among macrophytes should be adequately understood. Planktonic species have developed morphological and physiological adaptive strategies for surviving in different environments based on nutrients (Kumar and Oommen, 2009).

Grazing and nutrients recycling by zooplankton and macrophytes associated microinvertebrates are potential mechanisms for effecting control over primary producers in the aquatic ecosystem (Zrum and Hann, 1997).

Aquatic macrophytes play a significant role in maintaining water quality. Their presence may enhance water quality due to their ability to absorb excessive loads of nutrients. Aquatic floating macrophytes take up inorganic nutrients, mainly nitrogen and phosphorus, by the roots, although uptake through the leaves may also be significant (Ferdoushi et al., 2008).

Despite the widespread occurrence of Eichhornia azurea and Salvinia auriculata in shallow freshwater reservoirs of subtropical regions and their environmental importance, scanty information exists on the communities associated with the water-supply to aquaculture farms.

Because of insufficient knowledge about macrophytes in shallow water-supply reservoirs to aquaculture, we cannot adequately predict if this kind of system could work as a tool for maintenance of good conditions in the water-supply through bio-filtration of organic and inorganic pollutants.

The aim of this study was to investigate the effects of Eichhornia azurea and Salvinia auriculata macrophytes in maintaining water quality and communities associated in a water-supply reservoir to aquaculture farming. It was hypothesised that: i)- the community attributes (abundance and diversity) change in areas dominated by E. azurea or in areas with $S$. auriculata; ii)- the water parameters influence these attributes; iii)- the presence of $E$. azurea and $S$. auriculata has a positive effect on the water quality to water-supply reservoirs for aquaculture.

\section{Material and Methods}

\subsection{Study area}

Investigations were carried out on an aquaculture farm (21 $1^{\circ} 14^{\prime} 09^{\prime} ' \mathrm{~S}$; $\left.48^{\circ} 18^{\prime} 38^{\prime \prime} \mathrm{W}\right)$ in a shallow watersupply reservoir with continuous water flow, surface area of 3,800 $\mathrm{m}^{2}$ and water depth of 1-1.2 m, close to an agricultural area. According to the Köpen classification, the region's climate is Cwc, featuring subtropical climate with a relatively dry period in the winter (June to September) and a rainy one in the summer (December to March), with mean yearly temperature at $22^{\circ} \mathrm{C}$ and mean altitude $605 \mathrm{~m}$ (Peel et al., 2007).

The shallow reservoir under analysis had been formerly used as a fishpond. Since 1995, it has been only used to water-supply to aquaculture farm and is currently almost totally covered by macrophytes. The shallow reservoir is greatly affected by continuous water flow, wind, rainfall, transported nutrients and allochthonous materials that 
alter the physical and chemical characteristics of the water column. The macrophytes Eichhornia azurea (Sw.) Kunth and Salvinia auriculata Aublet are prevalent in the shallow water-supply reservoir. Whereas the former is a floating perennial aquatic plant, typically rooted in mud, the latter is a free-floating aquatic macrophyte, annual or perennial, with small-size leaves.

\subsection{Associated communities}

Sampling was performed at quarterly intervals during one year, August-2008, December-2008, March-2009 and June2009, at two sites, in areas dominated by E. azurea (Ea) and in those dominated by S. auriculata (Sa). Macrophytes were collected with $0.5 \mathrm{~m}^{2}$ floating quadrants. In the laboratory, the plants were carefully washed in distilled water, to remove adhered periphyton and organic and inorganic particulate matter. Next, the plants were sieved with $1 \mathrm{~mm}, 250 \mu \mathrm{m}$ and $58 \mu \mathrm{m}$ sieves. After washing the plants, communities associated were preserved in $4 \%$ formalin and $1 \%$ lugol iodine solution and stored in amber glass jars. Rotifera samples were analysed using a Sedgewick-Rafter counting cell and examined under $100 \mathrm{x}$ magnification. Cladocera and Copepoda were counted in acrylic cuvetts under a stereoscopic microscope. The phytoplankton samples were place in sedimentation chambers for 30 minutes, after which the organisms (cells, colonies and filaments) were examined under $400 \mathrm{x}$ magnification. Approximately four hundred specimens of the most abundant species were registered, with an approximate $10 \%$ precision and a $95 \%$ confidence interval (Bicudo and Bicudo, 2004). Ostracoda and Oligochaeta were identified as a class and Insecta was identified as adults and larvae. Taxonomic identification followed the specialised literature (Koste, 1978; Reid, 1985; Merrit and Cummins, 1996; Elmoor-Loureiro, 1997; Bicudo and Menezes, 2006).

\subsection{Plants}

All plant material in the quadrant was harvested and measured for nutrients (total phosphorus-TP and total nitrogen-TN), dry weight, wet weight and organic matter. After washing the plants, this material was placed in an oven to determine dry plant weight by storing for $72 \mathrm{~h}$ at $60^{\circ} \mathrm{C}$ until the weight stabilisation given by complete dehydration. Organic matter contents was determined in $0.3 \mathrm{~g}$ of the dry material and incinerated at $550^{\circ} \mathrm{C}$ over $4 \mathrm{~h}$. Plant TP and TN contents were determined in $0.3 \mathrm{~g}$ of macrophyte dry samples according to Andersen (1976).

\subsection{Water}

Physical and chemical parameters of water were measured in two samples sites, area with E. azurea and area with $S$. auriculata and collected at $0.10 \mathrm{~m}$ depth with a $5-\mathrm{L}$ Van Dorn bottle. Nitrate, ammonia, nitrite, orthophosphate and total phosphorus were evaluated in the same period of communities associated according to Golterman et al. (1978) and Koroleff (1976). Chlorophyll- $a$ was extracted with $90 \%$ alcohol and quantified at 663 and $750 \mathrm{~nm}$ (Nusch, 1980). Conductivity, $\mathrm{pH}$ and temperature were measured with a multiparametric probe HORIBA U-10 and water transparency was determined by a Secchi disk.

\subsection{Statistical analysis}

Mann-Whitney non-parametric test (Siegel, 1975) was employed to compare water and plants characteristics between sites (area with $E$. azurea and area with $S$. auriculata) and study period (August and December/08; March and June/09) $(n=8)$. Pearson correlation $(\mathrm{p}<0.05)$ was used to measure the significance relationship between the macrophytes, communities associated and environment parameters.

\section{Results}

Water transparency in Ea and Sa sites was similar $(\mathrm{p}<0.05)$ throughout the period (Table 1$)$. The $\mathrm{pH}$ ranged between 7 and 8 at the two sites (Ea and $\mathrm{Sa}$ ) and was directly correlated with $E$. azurea dry weight and inversely correlated with $S$. auriculata dry weight (Tables 1 and 2). The highest water conductivity value $\left(55 \mathrm{mS} . \mathrm{cm}^{-1}\right)$ was observed in March 2009 (end of the rainy season) in the Ea site. Conductivity was similar $(p>0.05)$ between sites but different $(\mathrm{p}<0.05)$ in the periods (Table 1$)$, and was directly correlated with $E$. azurea dry weight and inversely correlated with $S$. auriculata dry weight (Table 2).

The water temperature was similar $(\mathrm{p}>0.05)$ between sites and period and was directly correlated with $E$. azurea dry weight (Table 2). Nitrate in the water column was predominant among nitrogen compounds. Ammonia varied between 7.5 and $106 \mathrm{mg} . \mathrm{L}^{-1}$ during the study period and was similar $(\mathrm{p}>0.05)$ between sites and periods. Nitrite varied $(p<0.05)$ during the period (Table 1$)$. Total phosphorus and orthophosphate concentrations in the water column were low, below $50.9 \mathrm{mg} . \mathrm{L}^{-1}$, and total phosphorus was directly correlated with E. azurea dry weight (Tables 1 and 2). Chlorophyll- $a$ contents were similar $(\mathrm{p}>0.05)$ between sites and periods, but positively correlated with $E$. azurea dry weight and total phosphorus (Tables 1 and 2).

Highest plant dry weight (318.9 g.m²), wet weight $\left(3,327.8 \mathrm{~g} \cdot \mathrm{m}^{2}\right)$, organic matter $(84.6 \%)$, total phosphorus $(0.95 \% \mathrm{DW})$ and total nitrogen $(1.61 \% \mathrm{DW})$ occurred in E. azurea (Figure 1). Plant dry weight, organic matter and total nitrogen were significantly different $(p<0.05)$ between sites. Plant total nitrogen content in S. auriculata was directly correlated with nitrite and ammonia of water column (Figure 1; Tables 1 and 2).

The phytoplankton community consisted of 24 taxa. The Zygnematophyceae species were the most representative, followed by Chlorophyceae, Bacillariophyceae, Cyanobacteria, Oedogoniophyceae and Microsporaceae (Figure 2; Table 3). The algae species were correlated with E. azurea and S. auriculata biomass. Chlorophyceae, Zygnematophyceae and Oedogoniophyceae groups were directly correlated with $S$. auriculata organic matter and total nitrogen. However, only the Chlorophyceae species were inversely correlated with $S$. auriculata wet weight and total phosphorus (Table 2). 
The zooplankton community consisted of 18 taxa, 10 Rotifera, 3 Cladocera, 3 Protozoa and 2 Copepoda. The groups of Insecta, Oligochaeta and Ostracoda had low contribution while Ostracoda was positively correlated with E. azurea wet weight (Figure 3; Table 2). Rotifera and Protozoa species were dominant at the sample sites (Ea and $\mathrm{Sa}$ ) throughout the study period, mainly due to genera Lecane, Proales, Proalinopsis, Colurella, Diflugia and

Table 1. Mean, minimum and maximum (in brackets) of some limnological parameters and plant dry weight, wet weight, total phosphorus, total nitrogen of Eichhornia azurea and Salvinia auriculata, and results of Mann Whitney test (U) between sites $(\mathrm{Ea}=$ Eichhornia azurea and $\mathrm{Sa}=$ Salvinia auriculata $)$ and study period, ${ }^{*}=$ significance $(\mathrm{p}<0.05), \mathrm{n}=8, \mathrm{nd}=\mathrm{not}$ detected.

\begin{tabular}{lcccc}
\hline \multicolumn{1}{c}{ Parameters } & Ea & Sa & U (sites) & U (periods) \\
\hline Water Column & & & -0.28 & 1.58 \\
Chlorophyll- $a\left(\mu \mathrm{g} . \mathrm{L}^{-1}\right)$ & $3.8(\mathrm{nd}-11.2)$ & $4.2(1.4-11.2)$ & 0.00 & $-2.31^{*}$ \\
$\mathrm{pH}$ & $7.7(7.0-8.0)$ & $7.6(7.2-8.0)$ & 0.72 & 0.72 \\
Transparency $(\mathrm{cm})$ & $111.3(90-130)$ & $106.3(95-110)$ & -0.14 & $-2.02^{*}$ \\
Conductivity $\left(\mu \mathrm{S} . \mathrm{cm}^{-1}\right)$ & $49.5(47-55)$ & $48.3(47-49)$ & 0.72 & -1.15 \\
Temperature $\left({ }^{\circ} \mathrm{C}\right)$ & $21.4(18.8-23.8)$ & $21.5(18.7-23.8)$ & -0.58 & -1.44 \\
Ammonia $\left(\mu \mathrm{g} . \mathrm{L}^{-1}\right)$ & $35.8(11-103)$ & $39.2(7.5-106)$ & 0.58 & $-2.31^{*}$ \\
Nitrite $\left(\mu \mathrm{g} . \mathrm{L}^{-1}\right)$ & $3.9(2.2-5.6)$ & $1.9(2.7-4.8)$ & -0.29 & 1.44 \\
Nitrate $\left(\mu \mathrm{g} . \mathrm{L}^{-1}\right)$ & $542.3(474-730)$ & $535.2(429-627.4)$ & 0.00 & $-2.31^{*}$ \\
Orthophosphate $\left(\mu \mathrm{g} . \mathrm{L}^{-1}\right)$ & $4.1(\mathrm{nd}-15)$ & $3.3(\mathrm{nd}-10.3)$ & -0.29 & $-2.31^{*}$ \\
Total Phosphorus $\left(\mu \mathrm{g} . \mathrm{L}^{-1}\right)$ & $30.3(11.7-44.4)$ & $30.3(11.6-50.9)$ & $2.31^{*}$ & -0.28 \\
Plants & & & 1.44 & 0.00 \\
Dry Weight $\left(\mathrm{g} \cdot \mathrm{m}^{-2}\right)$ & $318.9(242-415)$ & $123(88-177)$ & $2.31^{*}$ & -0.58 \\
Wet Weight $\left(\mathrm{g} \cdot \mathrm{m}^{-2}\right)$ & $328(2173-4159)$ & $2393(1713-3285)$ & 1.44 & 0.86 \\
Organic Matter $(\% \mathrm{DW})$ & $84.6(84-85)$ & $79.1(74.3-82.2)$ & $2.31^{*}$ & -0.58 \\
Total Phosphorus $(\% \mathrm{DW})$ & $0.9(0.8-0.9)$ & $0.8(0.7-0.9)$ & $1.0(1.0-1.0)$ & \\
Total Nitrogen $(\% \mathrm{DW})$ & $1.6(1.6-1.7)$ & & & \\
\hline
\end{tabular}

Table 2. Pearson correlation between limnological parameters with Eichhornia azurea (Ea) and Salvinia auriculata (Sa); and organisms with Eichhornia azurea $(\mathrm{Ea})$ and Salvinia auriculata $(\mathrm{Sa}),(\mathrm{p}<0.05) \mathrm{DW}=$ dry weight, $\mathrm{WW}=$ wet weight, $\mathrm{OM}=$ organic matter, $\mathrm{TP}=$ total phosphorus, $\mathrm{TN}=$ total nitrogen; - = not correlated.

\begin{tabular}{lcclcc}
\hline \multicolumn{1}{c}{ Limnological Parameters } & Ea & Sa & \multicolumn{1}{c}{ Organisms } & Ea & Sa \\
\hline Temperature and DW & 0.99 & -0.74 & Cyanobacteria and WW & 0.86 & 0.89 \\
pH and DW & 0.99 & -0.71 & Cyanobacteria and TP & - & 0.89 \\
Conductivity and DW & 0.78 & -0.88 & Chlorophyceae and WW & 0.80 & -0.72 \\
Conductivity and TP & 0.85 & -0.88 & Chlorophyceae and TP & - & -0.72 \\
Conductivity and TN & - & 0.73 & Chlorophyceae and TN & - & 1.00 \\
Transparency and TP & -0.95 & - & Zygnematophyceae and WW & 0.81 & - \\
Total Phosphorus and DW & 0.86 & - & Zygnematophyceae and TN & - & 0.95 \\
Total Phosphorus and OM & - & 0.83 & Microsporaceae and WW & 0.68 & - \\
Total Phosphorus and TP & - & -0.76 & Bacillariophyceae and WW & 0.90 & 0.64 \\
Orthophosphate and DW & 0.79 & -0.51 & Oedogoniophyceae and WW & 0.79 & - \\
Orthophosphate and TP & 0.82 & - & Oedogoniophyceae and TN & - & 0.93 \\
Ammonia and OM & -0.48 & 0.73 & Rotifera and OM & -0.90 & - \\
Ammonia and TN & - & 0.95 & Rotifera and TP & -0.73 & - \\
Nitrate and DW & -0.70 & 0.86 & Protozoa and OM & - & 0.95 \\
Nitrate and OM & 0.70 & - & Calanoida and OM & -0.81 & - \\
Nitrate and TN & 0.76 & - & Cyclopoida and OM & -0.85 & - \\
Nitrite and DW & 0.98 & -0.78 & Ostracoda and WW & 0.94 & -0.83 \\
Nitrite and TN & - & 0.83 & Ostracoda and OM & - & 0.73 \\
Chlorophyll- $a$ and DW & 0.85 & - & Ostracoda and TP & -0.87 \\
Chlorophyll- $a$ and TP & 0.73 & - & Insecta and OM & -0.70 & - \\
\hline
\end{tabular}



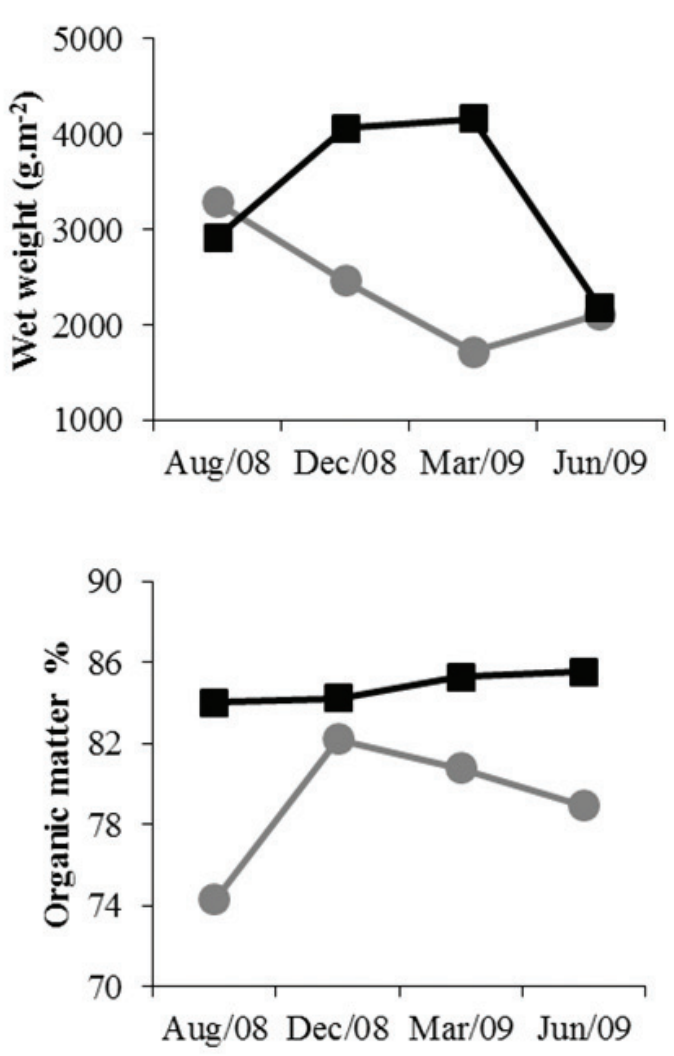
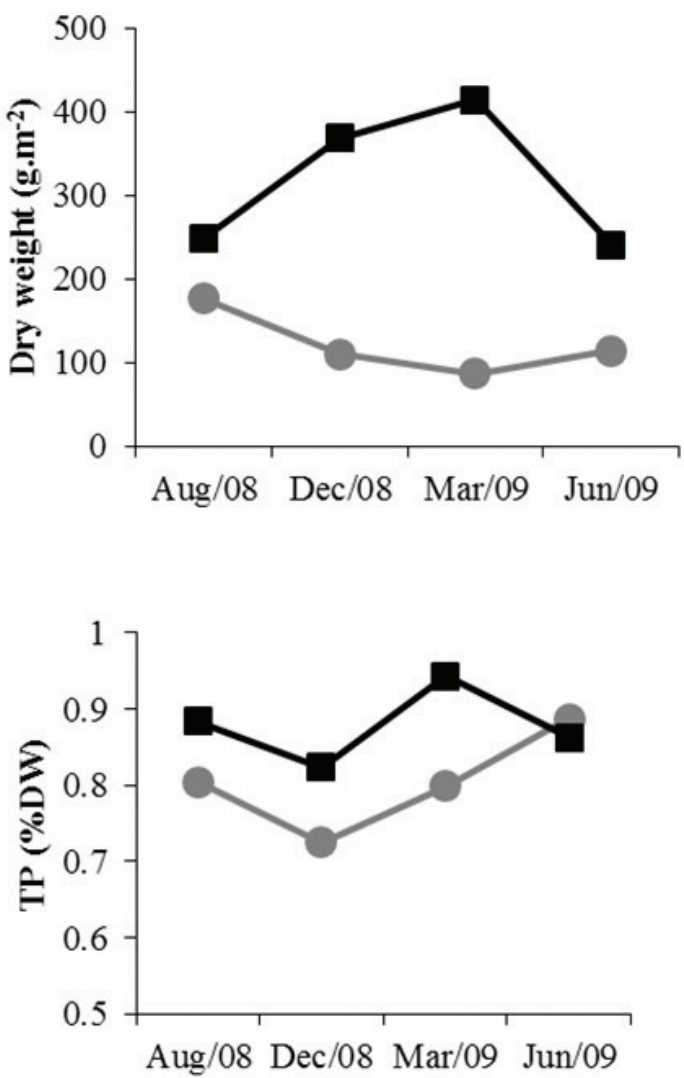

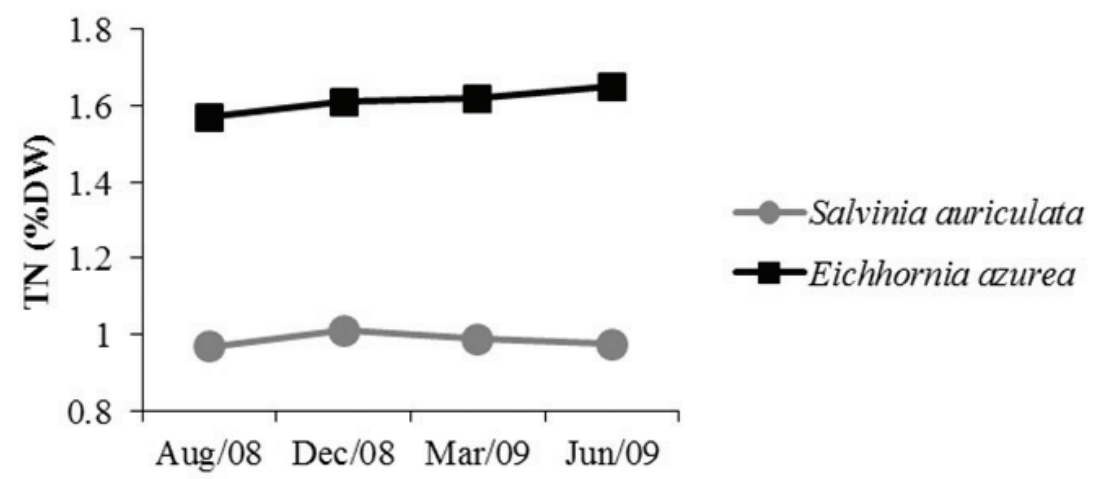

Figure 1. Dry weight, wet weight, organic matter, total nitrogen $(\mathrm{TN})$ and total phosphorus $(\mathrm{TP})$ of plants tissues during the study period.

Vorticella, whereas Rotifera species were most abundant among zooplankton community, with $89 \%$ of specimens in the Ea site and $93 \%$ of specimens in Sa one (Figure 3).

\section{Discussion}

The number of taxa found in the site Ea and Sa was similar in the shallow reservoir. These results can mostly be explained by macrophytes habitat and morphology present in this shallow reservoir, which both macrophytes are floating perennial aquatic plant or free-floating perennial or annual macrophytes. The number of planktonic taxa found was higher than those pointed by Albertoni et al. (2007) and lower than found by Onsem et al. (2010).

The species composition in any environment is ruled by prevailing environmental conditions (Begon et al., 2007). The associated faunal composition seems to be dependent on macrophyte form or structurally similar species, indicating that some species are present on most macrophytes but at different scales of abundance (Christie et al., 2009).

Where the period of macrophyte occupancy is log (such as this study), plant-associated zooplankton and invertebrate grazers may also preclude substancial phytoplankton development (Sayder et al., 2010). 

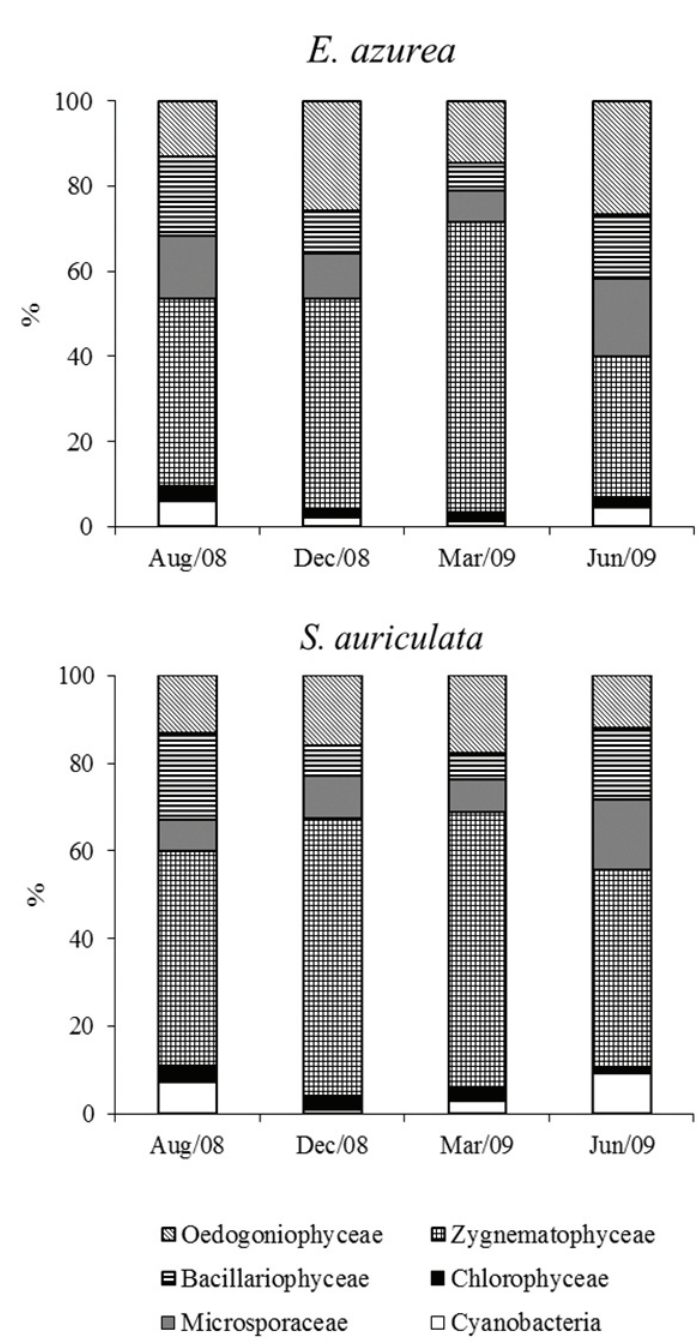

Figure 2. Relative abundance (\%) of phytoplankton associated with Eichhornia azurea and Salvinia auriculata macrophytes in the shallow water-supply reservoir.

Fast ammonia uptake by phytoplankton caused high Zygnematophyceae density. The presence of some phytoplankton species was related with organic matter and total nitrogen of plants, or directly correlated with macrophytes. Since Bogut et al. (2009) found a significantly higher number of organisms associated with macrophytes than in water or sediment samples, the authors concluded that variations in macrophyte communities influenced both composition and abundance of communities of associated.

Mulderij et al. (2005) reported that macrophytes may affect phytoplankton populations differentially, and that low concentrations of phosphorus in the environment may impede the development of macrophytes and allowing the dominance of epiphytic algae.

Our results showed that nutrients did not exert significant influence on the number of species associated with macrophytes. Since chlorophyll- $a$ rate was low and transparency was high, the retention of nutrients by plants occurred, which indicated beneficent plant growth.

The current study showed high plant organic matter, nitrogen and phosphorus contents in E. azurea. Similar contents were registered by Costa and Henry (2010) detected the highest contents of nitrogen and phosphorus in E. azurea plant tissue than S. auriculata and Cyperus esculents in the same environment.

Temperature influences the plankton communities, because phytoplankton and zooplankton may have different temperature optima for growth (Sayder et al., 2010). Mean temperature may indirectly determine the plankton through macrophytes, because the growth status of macrophytes at different temperatures may have different effects on environment conditions (i.e., chemical composition, organic matter) in the water column (Zeng et al., 2012). This seems to fit the observation in this study that temperature was positively correlated with E. azurea and that this macrophyte grew within a high temperature range.

The inverse correlation between E. azurea and $S$. auriculata biomass in the current study indicated competition for space and nutrients, mainly phosphorus. The macrophyte S. auriculata in conditions of competition for space, such as high density, tended to reduce its life cycle and produced more sporocarps (Sayder et al., 2010). After the death of plants, decomposition may also release large amounts of nutrients in the environment (Coelho et al., 2005).

An inverse correlation of phosphorus in S. auriculata plant tissue with the phosphorus of the water column has been reported in the current study. Salvinia auriculata has limited ability to remove phosphorus from only the first few centimetres of the water column, and E. azurea absorbs nutrients throughout the water column (Reddy et al., 1999).

Salvinia natans has a high growth rate on average with only ammonium and an intermediate growth rate when ammonia and nitrate are combined (Jampeetong and Brix, 2009). This study showed that total nitrogen in S. auriculata plant tissue was directly correlated with ammonia in the water column. Because the species is a free-floating macrophyte and had more contact with the water column volatile compounds. Most nitrogen, often accumulated in plant tissues, occurred in organic form in aquatic environments (Childers et al., 2006).

Rotifera in this study showed higher abundance and diversity. Taxa in this group are predominant in environments with human activities, because they have rapid reproduction and adaptation to environmental changes (Dahms et al., 2011). The dominance of Rotifera over Copepoda and Cladocera reflects an exploitative competition between the two zooplanktonic groups. This fact is also connected with different forms of algae, which constitute a food base for zooplankton. The structural complexity of aquatic vegetation is likely to provide a wide variety of potential havens for Crustacea predators.

A more diverse dominating structure representing limnological and littoral genera (Keratella sp., Bosmina sp.) in macrophyte stands is a result of their seeking refuge among architecturally complex habitats, coupled to the 
Table 3. Relative abundance (\%) composition of organisms associated with aquatic Eichhornia azurea (Ea) and Salvinia auriculata $(\mathrm{Sa})$ at shallow water-supply reservoir during the study period.

\begin{tabular}{|c|c|c|c|c|c|}
\hline Taxa & Ea & Sa & Taxa & Ea & Sa \\
\hline Cyanobacteria & & & Calanoida & & \\
\hline Microcystis aeruginosa (Kützing) Kützing & 2.5 & 4.7 & Argyrodiaptomus furcatus (Sars, 1901) & 0.1 & 0.3 \\
\hline Oscillatoria sp. & 1.1 & 0.3 & nauplii & 0.1 & 0.2 \\
\hline Chlorophyceae & & & Cyclopoida & & \\
\hline Ankistrodesmus falcatus (Corda) Ralfs & 0.5 & 0.7 & Termocyclops decipiens (Lowndes, 1934) & 0.6 & 1.3 \\
\hline Binuclearia sp. & 0.2 & 0.4 & nauplii & 0.2 & 0.6 \\
\hline Coelastrum microporum (Nageli) Kützing & 1.3 & 0.9 & Ostracoda & 0.4 & 0.4 \\
\hline Pediastrum duplex (Meyen) & 0.2 & 0.5 & Cladocera & & \\
\hline Scenedesmus quadricauda (Turpin) Brébison & 0.2 & 0.3 & Alona monocanta (Sars, 1901) & 0.2 & 0.5 \\
\hline Zygnematophyceae & & & Diaphanosoma birgei Korinek, 1981 & 0.1 & 0.2 \\
\hline Closterium acutum Brébison & 0.5 & 0.4 & Bosmina hagmani (Stingelin, 1904) & 0.1 & 0.1 \\
\hline Cosmarium sp. & 1.0 & 1.6 & Insecta & & \\
\hline Desmidium sp. & 0.4 & 0.4 & adult & 0.2 & 0.1 \\
\hline Micrasterias sp. & 0.9 & 0.5 & larvae & 0.9 & 0.8 \\
\hline Netrium digitus (Brébison) Ralfs & 1.2 & 1.9 & Oligochaeta & 0.2 & 0.1 \\
\hline $\begin{array}{l}\text { Pleurotaenium coronatum (Brébison) } \\
\text { Rabenhorst }\end{array}$ & 1.2 & 0.9 & Rotifera & & \\
\hline Spirogyra majuscula (Kützing) & 1.7 & 1.0 & Anuraeopsis fissa (Gosse, 1851) & 5.2 & 2.6 \\
\hline Spondylosium retangulare (Wolle) & 14.9 & 20.4 & Asplanchna sp. & 6.2 & 9.6 \\
\hline Staurastrum lobatos (Börjess) Bourrely & 1.1 & 0.6 & Brachionus calyciflorus (Pallas, 1766) & 3.0 & 8.0 \\
\hline Zygnema sp. & 25.6 & 27.5 & Colurella uncinata (Müller, 1773) & 6.2 & 5.0 \\
\hline Microsporaceae & & & Keratella cochlearis (Gosse, 1851) & 1.6 & 0.6 \\
\hline Microspora sp. & 12.8 & 10.2 & Lecane monostyla (Daday, 1897) & 18.0 & 12.4 \\
\hline Bacillariophyceae & & & Monnomata sp. & 10.7 & 4.5 \\
\hline Eunotia spp. & 2.1 & 4.2 & Proales doliaris (Rousselet, 1895) & 12.4 & 11.9 \\
\hline Melosira granulata (Ehr.) Ralfs & 9.1 & 6.8 & Proalinopsis caudatus (Collins, 1872) & 5.2 & 9.8 \\
\hline Nitzchia amphibia (Grunow) & 0.2 & 0.1 & Trichocerca longiseta (Schrank, 1802) & 4.1 & 8.0 \\
\hline Pinnularia sp. & 0.9 & 1.0 & Protozoa & & \\
\hline Surirella sp. & 0.2 & 0.2 & Arcella discoides Ehrenberg, 1843 & 4.1 & 10.0 \\
\hline Oedogoniophyceae & & & Difflugia corona Wallich, 1864 & 15.7 & 7.0 \\
\hline Oedogonium sp. & 20.0 & 14.7 & Vorticella $\mathrm{sp}$ & 4.2 & 5.9 \\
\hline
\end{tabular}

interactions between macrophyte-associated zooplankton and organisms which remain temporarily or permanently in the water within the plant site (Kuczyńska-Kippen and Świdnicki, 2008).

Protozoa was correlated with organic matter of S. auriculata plant tissues. According to Mieczan (2007), populations of Protozoa in aquatic environments are directly related to the presence of suspended solids, produced by macrophytes of fast life cycle, such as $S$. auriculata.

Positive correlation of Ostracoda and macrophytes indicated good conditions of the water column because the presence of these species in the water is considered an indicator of good water quality (Pieri et al., 2012). The Insecta community was low but was inversely correlated with organic matter of macrophytes indicating the grazing action on the plants.

The presence of dense, high-growing vegetation creates ample attachment and foraging ground for macrophyte- associated species and offers an effective refuge shelter for pelagic microinvertebrate species. Macrophyte stands may also be responsible for the existence or the amplification and compression of vertical gradients in physical-chemical parameters such as light and oxygen availability. This may increase the faunal diversity over the whole water column (Onsem et al., 2010).

Our results showed that the environmental variables associated with macrophytes presence in the shallow reservoir is strong predictors to favourable conditions for maintain of great diversity plankton community and macrofauna associated with plants. The management of areas neighbouring this reservoir actually favoured higher abundance of Rotifera species and nutrient enrichment, requiring an appreciation and understanding of landscape scale processes. Total nitrogen and total phosphorus in the macrophyte $E$. azurea showed a correlation with availability of nutrients in the water column, whereas dry weight was 

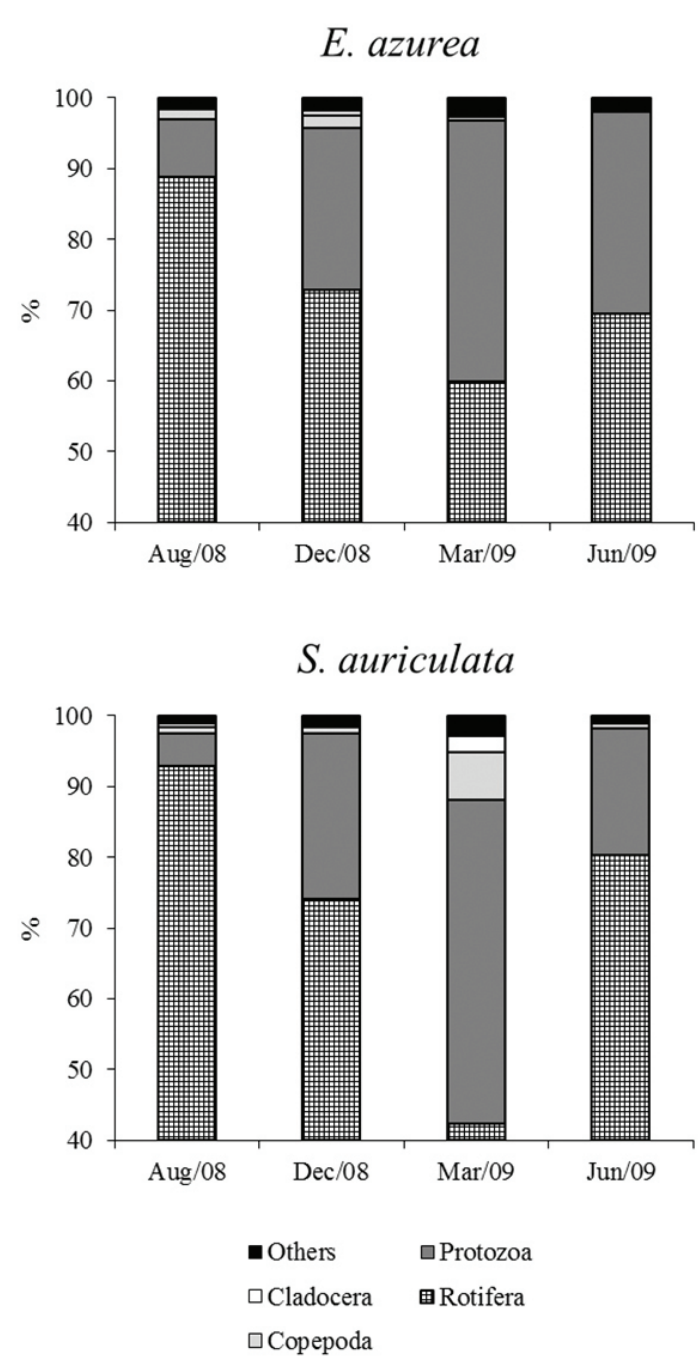

Figure 3. Relative abundance (\%) of organisms associated with Eichhornia azurea and Salvinia auriculata macrophytes in the shallow water-supply reservoir, Others = Insecta, Ostracoda and Oligochaeta.

directly correlated with phytoplankton biomass, which evidences the plants' effect in shallow water reservoir supply. This confirms the importance role of macrophytes not only in stabilising the clear-water state and maintaining high diversity of organisms associated, but also seems to be a good alternative to maintain desirable water-supply quality for aquaculture farm. Further studies aiming at evaluating the effect of macrophytes with significant role in maintaining water-supply quality, are thus encouraged.

Acknowledgements - The authors would like to thank FAPESP and CAPES for the scholarship to the second author. We heartily thank the working group of the Limnology Laboratory and Plankton Production and also Dr. Rodrigo Ney Millan.

\section{References}

ALBERTONI, EF., PRELLVITZ, LJ. and PALMA-SILVA, C., 2007. Macroinvertebrate fauna associated with Pistia stratiotes and Nymphoides indica in subtropical lakes (south Brazil). Revista Brasileira de Biologia = Brazilian Journal of Biology, vol. 67, no. 3, p. 499-507. http://dx.doi.org/10.1590/S151969842007000300015. PMid: 18094833

ANDERSEN, JM, 1976. An ignition method for determination of total phosphorus in lake sediments. Water Research, vol. 10, no. 4, p. 329-331. http://dx.doi.org/10.1016/0043-1354(76)90175-5.

BEGON, M.,TOWNSEND, CR. and HAPPER, JR., 2007. Ecologia: de indivíduos a ecossistemas. $4^{\text {th }}$ ed. Porto Alegre: Artmed. 752p.

BICUDO, CEM. and BICUDO, DC., 2004. Amostragem em Limnologia. São Carlos: Rima. 351 p.

BICUDO, CEM. and MENEZES, M., 2006. Gêneros de Algas de Águas Continentais do Brasil chave para identificação e descrições. $2^{\text {nd }}$ São Carlos: Rima. 489p.

BOGUT, I., VIDAKOVIC, J., CERBA, D. and PALIJAN, G., 2009. Epiphytic meiofauna in stands of different submerged macrophytes. Ekoloji, vol. 18, no. 70, p. 1-9. http://dx.doi. org/10.5053/ekoloji.2009.701.

CHILDERS, DL., BOYER, JN., DAVIS, SE., MADDEN, CJ., RUDNICK, DT. and SKLAR, FH., 2006. Relating precipitation and water management to nutrient concentrations in the oligotrophic "upside-down" estuaries of the Florida Everglades. Limnology and Oceanography, vol. 51, no. 1, part 2, p. 602-616. http:// dx.doi.org/10.4319/1o.2006.51.1_part_2.0602.

CHRISTIE, H., NORDERHAUG, KM. and FREDRIKSEN, S., 2009. Macrophytes as habitat for fauna. Marine Ecology Progress Series, vol. 396, no. 9, p. 221-233. http://dx.doi.org/10.3354/ meps08351.

COELHO, FF., LOPES, FS. and SPERBER, CF., 2005. Persistence strategy of Salvinia auriculata Aublet in temporary ponds of southern Pantanal, Brazil. Aquatic Botany, vol. 81, no. 4, p. 343352. http://dx.doi.org/10.1016/j.aquabot.2005.02.001.

COSTA, MLR. and HENRY, R., 2010. Phosphorus, nitrogen, and carbon contents of macrophyte in lakes lateral to a tropical river (Paranapanema River, São Paulo, Brazil). Acta Limnologica Brasiliensia, vol. 22, no. 2, p. 122-132. http://dx.doi.org/10.1590/ S2179-975X2010000200002.

DAHMS, HU., HAGIWARA, A. and LEE, JS., 2011. Ecotoxicology, ecophysiology, and mechanistic studies with rotifers. Aquatic Toxicology (Amsterdam, Netherlands), vol. 101, no. 1, p. 1-12. http://dx.doi.org/10.1016/j.aquatox.2010.09.006. PMid:20961628

ELMOOR-LOUREIRO, LMA., 1997. Manual de identificação de cladóceros límnicos do Brasil. Brasília: Editora da Universidade Católica de Brasília. 155p.

FERDOUSHI, Z., HAQUE, F., KHAN, S. and HAQUE, M., 2008. The effects of two aquatic floating macrophytes (Lemna and Azolla) as biofilters of nitrogen and phosphorus in fish ponds. Turkish Journal of Fisheries and Aquatic Sciences, vol. 8, no. 2, p. 253-258.

GOLTERMAN, HL., CLYMO, RS. and OHNSTAD, MAM., 1978. Methods for physical and chemical analysis of fresh water. $2^{\text {nd }}$ ed. Oxford: Blackwell Scientific Publication. 213 p. IBP Handbook, no. 8 . 
JAMPEETONG, A. and BRIX, H., 2009. Nitrogen nutrition of Salvinia natans: Effects of inorganic nitrogen form on growth, morphology, nitrate reductase activity and uptake kinetics of ammonium and nitrate. Aquatic Botany, vol. 90, no. 1, p. 67-73. http://dx.doi.org/10.1016/j.aquabot.2008.06.005.

KOROLEFF, F., 1976. Determination of ammonia. In GRASHOFF, E. and KREMLING, E. (Eds.) Methods of seawater analysis. German: Verlag Chemie Weinhein. p. 126-133.

KOSTE, W.,1978. Rotatoria Die Rädertiere Mitteleuropas, begründet von Max Voigt-Monogononta. 2.Auflage neubearbeitet von Walter Koste. Berlim: Gebrüder Borntraeger. 673p.

KUCZYŃSKA-KIPPEN, N. and ŚWIDNICKI, K.,2008. The spatial structure of zooplankton communities and trophic state of mid-city Strzeszynskie lake. Teka Kom.Ochr.Kszt.Srod.Przyr - OLPAN, vol. 5, p. 85-94.

KUMAR, NJI. and OOMMEN, C., 2009. Influence of limiting factors on phytoplankton and coliform population on an inundated, isolated wetland. Journal of Wetlands Ecology, vol. 3, no. 0, p. 43-55. http://dx.doi.org/10.3126/jowe.v3i0.2225.

MERRIT, RW. and CUMMINS, KW., 1996. An introduction to the aquatic insects of North America. $3^{\text {rd }}$ ed. Dubuque: Kendal/ Hunt. 862p.

MIECZAN, T., 2007. Size spectra and abundance of planktonic ciliates within various habitats in a macrophyte-dominated lake (Eastern Poland). Biologia, vol. 62, no. 2, p. 189-194. http:// dx.doi.org/10.2478/s11756-007-0028-1.

MULDERIJ, G., MOOIJ, W., SMOLDERS, AJP. and DONK, EV., 2005. Allelopathic inhibition of phytoplankton by exudates from Stratiotes aloides. Aquatic Botany, vol. 82, no. 4, p. 284-296. http://dx.doi.org/10.1016/j.aquabot.2005.04.001.

NUSCH, EA., 1980. Comparison of different methods for chlorophyll and phaeopigments determination. Archiv für Hydrobiologie, vol. 14 , p. 4-36.

ONSEM, SV., DE BACKER, S. and TRIEST, L., 2010. Microhabitatzooplankton relationship in extensive macrophyte vegetations of eutrophic clear-water ponds. Hydrobiolgia, vol. 656, no. 1, p. 67-81. http://dx.doi.org/10.1007/s10750-010-0442-1.

PEEL, MC., FINLAYSON, BL. and MCMAHON, TA., 2007. Updated world map of the Köppen-Geiger climate classification. Hydrology and Earth System Sciences, vol. 11, no. 5, p. 16331644. http://dx.doi.org/10.5194/hess-11-1633-2007.

PIERI, V., VANDEKERKHOVE, J. and GOI, D., 2012. Ostracoda (Crustacea) as indicators for surface water quality: a case study from the Ledra River Basin (NE Italy). Hydrobiologia, vol. 688, no. 1, p. 25-35. http://dx.doi.org/10.1007/s10750-010-0568-1.

REDDY, KR., KADLEC, RH., FLAIG, E. and GALE, PM., 1999. Phosphorus Retention in Streams and Wetlands: A Review. Critical Reviews in Environmental Science and Technology, vol. 29, no. 1, p. 83-146. http://dx.doi.org/10.1080/10643389991259182.

REID, JW., 1985. Chave de identificação e lista de referências bibliográficas para as espécies continentais sul-americanas de vida livre, ordem Cyclopoida (Crustacea, Copepoda). Boletim de Zoologia USP, vol. 9, p. 17-143.

RONZHINA, DA., IVANOV, LA. and P'YANKOV, VI., 2010. Chemical composition of leaves and structure of photosynthetic apparatus in aquatic higher plants. Russian Journal of Plant Physiology: a Comprehensive Russian Journal on Modern Phytophysiology, vol. 57, no. 3, p. 368-375. http://dx.doi. org/10.1134/S1021443710030088.

SANDILANDS, KA. and HANN, BJ., 1997. Is phytophilous zooplankton community structure affected by nutrients and fathead minnows? UFS (Delta Marsh). Annual Report, vol. 32, p. 47-54.

SAYDER, CD., DAVIDSON, TA. and JONES, JI., 2010. Seasonal dynamics of macrophytes and phytoplankton in shallow lakes: a eutrophication-driven pathway from plants to plankton? Freshwater Biology, vol. 55, no. 2, p. 500-513.

SIEGEL, S., 1975 Non-parametric statistics for the behavioral sciences. McGraw-Hill, Brazil, São Paulo.

ZENG, J., BIAN, Y., XING, P. and WU, QL., 2012. Macrophyte species drive the variation of bacterioplankton community composition in a shallow freshwater lake. Applied and Environmental Microbiology, vol. 78, no. 1, p. 177-184. http://dx.doi.org/10.1128/ AEM.05117-11. PMid:22038598

ZINGEL, P., NÕGES, P., TUVIKENE, L., FELDMENN, T., JÄRVALT, A., TÕNNO, I., AGASILD, H., TAMMERT, H., LUUP, H., SALUJÕE, J. and NÕGES, T., 2006. Ecological processes in macrophyte- and phytoplankton-dominates shallow lakes. Proceedings of the Estonian Academy of Sciences, Biology, Ecology, vol. 55, no. 4, p. 280-307.

ZRUM, L. and HANN, BJ., 1997. Planktonic microinvertebrate community structure in a prairie wetland in response to addition of inorganic nutrients and organophosphorus insecticide. UFS (Delta Marsh). Annual Report, vol. 32, p. 56-67. 